\title{
Analisis Bentuk Kemandirian Anak Di Desa Gondosari
}

\author{
Khintan Putri Aryani ${ }^{1}$, Erik Aditia Ismaya ${ }^{2}$, Mohammad Syaffruddin Kuryanto ${ }^{3}$ \\ Pendidikan Guru Sekolah Dasar, Universitas Muria Kudus \\ $\underline{\text { kintanaryani28@gmail.com }}^{1}$, erik.aditia@umk.ac.id ${ }^{2}, \underline{\text { syafruddin.kuryanto@umk.ac.id }}^{3}$
}

\begin{abstract}
Abstrak: Dalam penelitian ini memiliki tujuan mendeskripsikan bentuk kemandirian anak di Desa Gondosari. Metode penelitian yang digunakan yaitu penelitian kualitatif deskriptif. Teknik pengumpulan data meliputi observasi, wawancara, dokumentasi dan pencatatan. Sumber data primer yaitu 5 anak dan orang tua di Desa Gondosari. Sedangkan sumber data sekunder didapatkan melalui dokumentasi, catatan penelitian, dan pendukung lainnya. Hasil penelitian menunjukkan bahwa bentuk kemandirian anak di Desa Gondosari dapat dilihat pada saat anak melakukan aktivitas sehari-hari melalui tujuh indikator kemandirian anak yaitu: (1) kemampuan fisik, (2) percaya diri, (3) bertanggung jawab, (4) disiplin, (5) pandai bergaul, (6) saling berbagi, (7) mampu mengendalikan emosi. Dari hasil penelitian dapat disimpulkan bahwa anak-anak di Desa Gondosari sudah menunjukkan kemandiriannya tetapi dibeberapa poin anak-anak terlihat masih kurang mandiri.
\end{abstract}

Kata Kunci: Kemandirian; Anak.

Abstract: This research aims to describe the form of independence of children in Gondosari Village. The research method used is descriptive qualitative research. Data collection techniques include observation, interviews, documentation and recording. Primary data sources are 5 children and their parents in Gondosari Village. While secondary data sources are obtained through documentation, research notes, and other supports. The results showed that the form of independence of children in Gondosari Village can be seen when children carry out daily activities through seven indicators of child independence, namely: (1) physical ability, (2) self-confidence, (3) responsibility, (4) discipline, (5) good at getting along, (6) sharing, (7) able to control emotions. From the results of the study it can be concluded that the children in Gondosari Village have shown their independence but at some points the children seem to be less independent.

Keywords: Independence; Children.

\section{Pendahuluan}

Anak merupakan anugerah yang dimiliki oleh setiap orang tua. Sejak dilahirkan, ia menjadi pusat perhatian. Anak usia sekolah (6-12 tahun) berada pada masa dimana terjadinya perubahan dalam pertumbuhan dan perkembangan yang nantinya akan mempengaruhi pembentukan kepribadian dan karakteristik anak. Pada usia kanak-kanak merupakan peluang terbaik dalam mengembangkan potensi dan kemandirian anak.

Dalam pendidikan karakter terdapat 18 karakter untuk dikembangkan pada anak. Salah satunya yakni karakter mandiri. Mustari (2011) menyatakan bahwa mandiri merupakan sikap maupun perilaku dalam menyelesaikan tugasnya tidak bergantung pada orang lain. Sejalan dengan pendapat Sari dkk (2020) bahwa kemandirian ialah anak mampu mengatur diri dalam kegiatan sederhana yang dekat dengan anak dalam kehidupan sehari-hari. Dapat disimpulkan, mandiri adalah sikap maupun perilaku seseorang yang melakukan segala kegiatannya sendiri tanpa harus bergantung atau membebani orang lain. 
Kemandirian anak akan berbeda dengan kemandirian remaja dan orang dewasa. Apabila kemandirian pada orang dewasa yaitu kemampuan seseorang bertanggung jawab dalam apa yang dilakukannya tanpa bergantung dengan orang lain, untuk kemandirian masa anak-anak bersifat motorik seperti berusaha untuk mandi sendiri, memakai pakaian sendiri, makan dan minum sendiri, bahkan membereskan sendiri mainan setelah selesai bermain.

Berdasarkan hasil observasi yang dilakukan di Desa Gondosari menunjukkan bahwa bentuk kemandirian pada anak di Desa Gondosari dapat diukur melalui indikator-indikator kemandirian yang ditunjukkan pada aktivitas anak sehari-hari. Penelitian terdahulu yang telah meneliti mengenai bentuk kemandirian anak yaitu penelitian dari Chairilsyah (2019), dapat disimpulkan bahwa kemandirian anak di TK Pertiwi Riau pada usia 5-6 tahun berada pada kriteria mulai berkembang. Dilihat melalui indikator-indikator kemandirian anak diperoleh hasil yakni: (1) kemampuan fisik berada dalam kategori berkembang sesuai harapan. (2) percaya diri pada kriteria mulai berkembang, (3) bertanggung jawab pada kriteria mulai berkembang, (4) disiplin pada kriteria mulai berkembang, (5) pandai bergaul pada kriteria mulai berkembang, (6) saling berbagi pada kriteria mulai berkembang, (7) mampu mengendalikan emosi pada kriteria mulai berkembang.

Kemudian penelitian dari Utami dkk (2019) dapat disimpulkan bahwa kemandirian anak kelompok B di PAUD Segugus Lavender dalam kriteria baik dengan nilai presentasi berada pada angka 75,33\% yang meliputi hasil rata-rata dari tujuh indikator yaitu: (1) kemampuan fisik, dari nilai maksimum yakni 15 mendapat nilai rata-rata 11,57 sehingga dapat dikategorikan sangat baik. (2) percaya diri, dari nilai maksimum 15 mendapat nilai rata-rata 11,47 sehingga dapat dikategorikan baik. (3) tanggung jawab, dari nilai maksimum 15 mendapat nilai rata-rata yakni 11,57 sehingga dapat dikategorikan baik. (4) pandai bergaul, nilai rata-rata 10,00 dari nilai maksimum yakni 12 sehingga dapat dikategorikan baik, (5) disiplin, dari nilai maksimum yakni 15 mendapat nilai rata-rata 11,77 sehingga dapat dikategorikan baik. (6) saling berbagi, dari nilai maksimum 12 mendapat nilai rata-rata 9,4 sehingga dapat dikategorikan baik. (7) mampu mengendalikan emosi, dari nilai maksimum yanki 6 mendapat nilai rata-rata 4,8 sehingga dapat dikategorikan baik. Pada penelitan, terdapat 14 anak (46\% anak) berada dalam kriteria sangat baik, lalu 15 (30\%) anak berada dalam kriteria baik, dan 1 (3\%) anak berada dalam kriteria kurang baik.

Dari uraian diatas, penelitian ini akan membahas mengenai bentuk kemandirian anak di Desa Gondosari. Tujuannya adalah untuk menganalisis bentuk kemandirian anak di Desa Gondosari ditinjau dari tujuh indikator kemandirian anak yaitu (1) kemampuan fisik, (2) percaya diri, (3) bertanggung jawab, (4) disiplin, (5) pandai bergaul, (6) saling berbagi, (7) mampu mengendalikan emosi.

\section{Metode Penelitian}

Penelitian ini merupakan penelitian kualitatif deskriptif karena peneliti ingin mendeskripsikan keadaan yang diamati dilapangan dengan lebih transparan, spesifik, dan mendalam. Penelitian ini menggambarkan kejadian sehingga data yang terkumpul bersifat deskriptif. Penelitian ini mendeskripsikan secara jelas tentang fakta-fakta yang terjadi di lapangan terkait dengan bentuk kemandirian pada anak di Desa Gondosari.

Penelitian dilaksanakan di Desa Gondosari tepatnya di Kecamatan Gebog Kabupaten Kudus. Sumber data pada penelitian menggunakan sumber primer serta sumber sekunder. Adapun sumber primer yaitu 5 anak dan orang tua di Desa Gondosari. Sedangkan sumber sekunder diperoleh melalui dokumentasi, catatan penelitan dan pendukung lainnya. Dalam 
penelitian ini yang digunakan untuk teknik mengumpulkan data yaitu: 1) observasi, peneliti melakukan observasi tentang bentuk kemandirian anak di Desa Gondosari. 2) wawancara, dengan menggunakan pedoman wawancara yang ditujukan kepada 5 anak dan orang tua di Desa Gondosari. 3) dokumentasi, berupa foto-foto kejadian penting selama observasi maupun wawancara guna sebagai bukti nyata jika peneliti benar-benar melakukan penelitian. 4) pencatatan, peneliti menggunakan alat tulis serta lembar catatan yang sesuai dengan lembar pedoman observasi dan wawancara.

Dalam menganalisis data menggunakan 3 tahapan yaitu: 1) reduksi data untuk merangkum, memilih hal-hal inti serta memfokuskan pada hal-hal penting dari hasil catatan selama penelitian. 2) penyajian data untuk menyajikan data dari reduksi data dalam bentuk teks yang bersifat naratif. 3) kesimpulan untuk mengambil inti pada sajian data dalam bentuk pernyataan kalimat.

\section{Hasil dan Pembahasan}

Berdasarkan hasil observasi dan wawancara yang telah dilakukan pada setiap anak dan orang tua di Desa Gondosari, selanjutnya membahas mengenai hasil penelitian dengan mengacu pada rumusan masalah yakni bagaimana bentuk kemandirian anak di Desa Gondosari. Berdasarkan dari hasil penelitian terdapat temuan bahwa bentuk kemandirian anak di Desa Gondosari dapat ditinjau melalui tujuh indikator kemandirian yaitu (1) kemampuan fisik, (2) percaya diri, (3) bertanggung jawab, (4) disiplin, (5) pandai bergaul, (6) saling berbagi, (7) mampu mengendalikan emosi. Sejalan dengan pendapat Yamin dan Sanan (2010) bahwa aspek kemandirian pada anak dapat ditinjau melalui tujuh indikator yaitu: (1) kemandirian fisik, (2) percaya diri, (3) bertanggung jawab, (4) disiplin, (5) pandai bergaul, (6) saling berbagi, (7) mampu mengendalikan emosi.

Kemampuan fisik dalam kegiatan anak sehari-hari bisa dilihat melalui kemampuan untuk mandi, memakai pakaian, dan makan sendiri serta menyiapkan keperluannya sendiri tanpa meminta bantuan orang tua atau orang lain disekitarnya. Sejalan dengan pendapat Nova dan Widiastuti (2019) bahwa karakter mandiri anak bisa diterapkan melalui aktivitas kesehariannya. Kemudian senada dengan pendapat Yuliani dkk (2014) bahwa melatih kemandirian anak bisa dilakukan dengan melibatkan anak pada kegiatan sehari-hari dirumah seperti mengambil air minum sendiri, melatih anak membersihkan kamar sendiri, melatih untuk makan sendiri, dan sebagainya. Namun berdasarkan hasil penelitian pada poin "mandi sendiri" masih terdapat 1 anak yang masih dimandikan ibunya. Anak tersebut berusia 6 tahun. Alasan ibu masih memandikan anak karena ketika anak mandi sendiri tidak bersih.

Dalam aspek percaya diri, anak-anak mampu memilih mainan atau pakaian sendiri sesuai dengan yang diinginkan, berani mengantar makanan ke tetangga dan menyapa orang lain, tidak merasa malu jika bertemu orang baru. Namun dari hasil penelitian, masih terdapat 2 anak yang malu bertemu orang baru. Desmita (2009) menyatakan bahwa kemandirian muncul serta berfungsi disaat anak menemukan dirinya pada kondisi dimana dituntut suatu tingkat kepercayaan diri anak. Kemudian Widyanti dkk (2017) berpendapat bahwa percaya diri ialah keyakian yang dimiliki oleh seseorang yang mampu berperilaku seperti yang dibutuhkan guna mendapatkan hasil yang diinginkan.

Pada aspek tanggung jawab, anak-anak di Desa Gondosari mau untuk meminta maaf ketika melakukan kesalahan dan mengembalikan barang ketika sudah selesai ia pinjam. Utami dkk (2019) berpendapat bahwa dengan sikap tanggung jawab pada anak menjadikan anak akan lebih berhati-hati pada saat bertindak guna meminimalisir kesalahan dengan belajar dari suatu 
kesalahan yang pernah dilakukan, hal tersebut akan menjadikan anak belajar dari pengalaman. Sejalan dengan pendapat Ridwan dan Mudiono (2017) bahwa adanya rasa tanggung jawab pada anak akan mendorong anak senantiasa melakukan hak serta kewajiban sebagaimana semestinya yang ia harus lakukan. Namun pada poin "merapikan mainan sendiri setelah selesai bermain" terdapat 1 anak yang masih dibantu orang tua. Selain itu pada poin "mengembalikan piring dan gelas ke dapur setelah makan" masih terdapat 1 anak yang belum tampak inisiatifnya untuk mengembalikan piring dan gelas sendiri, anak tersebut harus disuruh terlebih dahulu.

Pada aspek disiplin, anak-anak di Desa Gondosari rata-rata sudah mematuhi aturan yang diterapkan oleh orang tua di rumah tetapi masih ada 1 anak yang terkadang tidak mematuhi aturan, lalu anak-anak berpamitan kepada orang tua atau kakak ketika akan pergi. Sejalan dengan pendapat Ariansyah dkk (2019) bahwa salah satu strategi yang bisa membuat anak menjadi mandiri adalah kedisiplinan, melalui sikap disiplin dapat menjaga anak dari perilaku yang menyimpang. Ridwan dan Mudiono (2017) berpendapat bahwa sangat penting mengembangkan kedisiplinan pada diri anak agar anak dapat menjalani kehidupan yang teratur serta dapat meraih keberhasilan dengan mudah. Kemudian pendapat dari Nihayati dkk (2021) yang menyatakan bahwa melalui kegiatan keseharian yang telah diberikan peraturan dalam setiap kegiatan, seiring berjalannya waktu maka akan terbentuk sikap disiplin dengan sendirinya walau pada awalnya terlihat berat. Namun menurut hasil penelitan, dalam poin "bangun pagi sendiri" anak-anak terkadang masih dibangunkan orang tuanya.

Selain itu, pada aspek pandai bergaul, anak-anak mengenal semua nama temannya dan mau bermain bersama. Namun terdapat 1 anak yang hanya mengenal beberapa nama temannya saja. Kemudian anak-anak berani untuk berangkat sekolah dengan teman tanpa harus diantar orang tua. Sejalan dengan pendapat Yamin (2012) bahwa pandai bergaul ialah anak mampu untuk menempatkan diri dimanapun anak tinggal dan mampu bersosialisasi dengan lingkungan. Lalu pendapat dari Yanti (2016) mengatakan bahwa anak yang pandai bergaul dikategorikan terampil secara sosial, mempunyai kemampuan untuk mengenal, menghadapi bermacam karakter orang, serta menginterprestasikan dalam memberikan pendapat yang tepat terhadap berbagai situasi sosial.

Kemudian bentuk kemandirian pada kategori saling berbagi, anak-anak mau berbagi makanan dan mainan, mau meminjamkan pensil atau pulpen kepada teman jika ada yang tidak membawa. Sejalan dengan pendapat Yamin (2012) yang menyatakan bahwa anak yang mandiri menunjukkan sikap dengan meminjamkan mainan atau alat tulis, berbagi makanan, serta membantu teman ketika mengalami kesulitan. Kemudian senada dengan pendapat Utami dkk (2019) dengan saling berbagi bisa membantu kebutuhan orang lain. Namun pada poin "mau bergantian saat menonton TV" masih terdapat 2 anak yang tidak mau bergantian ketika sedang menonton televisi.

Pada aspek mengendalikan emosi, anak-anak mulai mampu menahan diri untuk tidak memaksa dan menuntut orang tuanya untuk mewujudkan segala keinginannya. Anak-anak berbicara dengan sopan saat memberitahu apa yang dia inginkan dan mampu mengekspresikan emosi sesuai dengan kondisi yang ada. Sejalan dengan pendapat Chairilsyah (2019) kemandirian pada anak bisa dilihat melalui kegiatan keseharian anak yang terwujud dalam perilaku emosi pada kehidupan sosialnya. Kemudian Yamin (2012) berpendapat bahwa mengendalikan emosi adalah anak mampu untuk mengontrol emosi dan memiliki rasa empati kepada orang-orang disekitarnya. 
Berdasarkan dari hasil penelitian dan pembahasan yang dilakukan, secara umum anak-anak di Desa Gondosari menunjukkan sikap kemandirian yang baik. Selain itu pada bentuk kemandirian dilihat dari tujuh indikator, rata-rata anak dalam klasifikasi baik.

\section{Kesimpulan dan Saran}

Berdasarkan dari hasil penelitian dan pembahasan, dapat disimpulkan bahwa bentuk kemandirian anak di Desa Gondosari dapat dilihat melalui tujuh indikator yaitu: (1) kemampuan fisik, pada poin "mandi sendiri" masih terdapat 1 anak yang masih dimandikan ibunya. (2) percaya diri, terdapat 2 anak yang malu apabila bertemu orang baru. (3) tanggung jawab, pada poin "merapikan mainan sendiri setelah selesai bermain" terdapat 1 anak yang masih dibantu orang tua dan poin "mengembalikan piring dan gelas ke dapur setelah makan" masih terdapat 1 anak yang belum tampak inisiatifnya untuk mengembalikan piring dan gelas sendiri. (4) disiplin, dalam poin "bangun pagi sendiri" anak-anak terkadang masih dibangunkan orang tuanya. (5) pandai bergaul, pada poin "mengenal semua nama teman" terdapat 1 anak yang hanya mengenal beberapa nama temannya. (6) saling berbagi, dalam poin "mau bergantian saat menonton TV" masih terdapat 2 anak yang tidak mau bergantian ketika sedang menonton televisi. (7) mampu mengendalikan emosi, anak-anak mulai mampu menahan diri untuk tidak memaksa dan menuntut orang tuanya untuk mewujudkan segala keinginannya.

Berdasarkan penelitian yang sudah dilakukan, maka saran yang dapat diuraikan sebagai berikut: 1. Bagi orang tua, diharapkan selalu memberikan dampak positif terhadap perkembangan anak khususnya pada aspek kemandirian sehingga anak mempunyai kepribadian yang mandiri. Kemudian, hendaknya orang tua tetap mengalokasikan waktunya untuk memperhatikan perkembangan anak pada berbagai aspek agar dapat tercapai perkembangan anak secara maksimal. 2. Bagi peneliti selanjutnya, diharapkan dapat mengembangkan penelitian ini dengan fokus penelitian yang lebih menarik sehingga dapat mengkaji lebih dalam lagi terhadap bentuk kemandirian pada anak. Adanya penelitan ini diharapkan memperoleh pemahaman yang diperlukan.

\section{Daftar Pustaka}

Ariansyah, M,. Juarsa, O., \& Hambali, D. (2019). Pengaruh Kedisiplinan Siswa Terhadap Kemandirian Belajar Kelas V SDN Gugus 4 Kabupaten Rejang Lebong. JURIDIKDAS: Jurnal Riset Pendidikan Dasar, 2 (2). 126-134.

Chairilsyah, D. (2019). Analisis Kemandirian Anak Usia Dini. PAUD Lectura: Jurnal Pendidikan Anak Usia Dini, 3 (1), 88-98.

Desmita. (2009). Psikologi Perkembangan Peserta Didik. Bandung: Remaja Rosdakarya. Mustari, M. (2011). Nilai Karakter. Yogyakarta: LaksBang PRESSindo.

Nasucha, A., Nur'aini, T. A., \& Indriawati, P. (2019). Perbedaan Kemandirian Anak Usia Pra Sekolah Ditinjau Dari Ibu Bekerja Dan Ibu Rumah Tangga Di Sekolah Alam Jabalussalam Balikpapan Tahun Ajaran 2017/2018. Jurnal Edueco, 2 (1), 1-4.

Nihayati, I., Ismaya, E. A., \& Oktavianti, I. (2021). Pendidikan Karakter Disiplin Pada Santri Pondok Pesantren Slaf Terpadu Bahjatur Roghibiin Kudus. Jurnal Inovasi Penelitan, 1 (11), 2395-2402.

Nova, D. D. R., \& Widiastuti, N. (2019). Pembentukan Karakter Mandiri Anak Melalui Kegiatan Naik Transportasi Umum. Comm-Edu (Community Education Journal), 2(2), 113-118. 
Ridwan, M. H., \& Mudiono, A. (2017). Analisis Muatan Nilai-Nilai Karakter Pada Buku Siswa Kelas IV Sekolah Dasar Tema Indahnya Kebersamaan. Wahana Sekolah Dasar, 25 (1), 1-7.

Sari, M., Ahmad. A., \& Rahmi. (2020). Pengembangan Karakter Mandiri Anak Usia Dini Di TK Aisyiyah Bustanul Arhfal Batoh Banda Aceh. Jurnal Ilmiah Mahasiswa Pendidikan Guru Anak Usia Dini, 5 (2), 98-108.

Suardani, L., Pudjawan, K., \& Tirtayani, L. A. (2016). Perbedaan Tingkat Kemandirian Anak Usia Dini 5-6 Tahun Dilihat Dari Status Pekerjaan Ibu Di Kelurahan Banyuning. Jurnal Pendidikan Anak Usia Dini Undiksha, 4 (2).

Utami, T. W. P., Nasirun, M., \& Ardina, M. (2019). Studi Deskiptif Kemandirian Anak Kelompok B di PAUD Segugus Lavender. Jurnal Ilmiah Potensia, 4 (2), 151-160.

Widyanti, I. F., Sudarma, I. K., \& Riastini, P. N. (2017). Kecenderungan Kualitas Rasa Percaya Diri Siswa Kelas V Sd Negeri 2 Sukasada Kabupaten Buleleng. e-Journal PGSD Universitas Pendidikan Ganesha, 5 (2), 1-10.

Yamin, M., \& Sanan, S. (2010). Panduan Pendidikan Anak Usia Dini. Jakarta: Gaung Persada Press.

Yanti, S. (2016). Kemampuan Bersosialisasi Pada Siswa Kelas XI Di SMA Negeri 8 Makassar. Jurnal Sosialisasi: Jurnal Hasil Pemikiran, Penelitian Dan Pengembangan Keilmuan Sosiologi Pendidikan, 3 (2).

Yuliani, A., Hufad, A., \& Sardin. (2014). Penanaman Nilai Kemandirian Pada Anak Usia Dini (Studi Pada Keluarga Di Rw 05 Kelurahan Sindangkasih Kecamatan Beber Cirebon). Jurnal Pendidikan Luar Sekolah, 9(2). 